Section of Anthropology, on "New World Contributions to Old World Culture." Prof. Welch hefore the Section of Physiology and Experimental Medicine. Prof. J. J. Flather before the Section of Mechanical Science and Engineering, on "Modern Tendencies in the Utilisation of Power." Prof. C. C. Nutting before the Section of Zoology, on "Some of the Perplexities of a Systematist." Prof. D. H. Campbell before the Section of Botany, on "The Origin of Terrestrial Plants." Prof. Wright before the Section of Social and Economic Science, on "The Psychology of the Labour Question."

Many important scientific bodies met in affiliation with the Association. Among these were:-The American Anthropological Association, the American Chemical Society, the American Folk-lore Society, the American Microscopical Society, the American Morphological Society, the American Yhilosophical Association, the American Physical Society, the American Physiological Society, the American Psychological Association, the American Society of Naturalists, the Association of American Anatomists, the Association of Economic Entomologists, the Astronomical and Astrophysical Society of America, the Botanical Society of America, the Botanists of the Central and Western States, the Geological Society of America, the National Geographic Society, the Naturalists of the Central States, the Society of American Bacteriologists, the Society for Plant Morphology and Physiology, the Society for the Promotion of Agricultural Science, the Zoologists of the Central and Western States.

The approximate register of scientific men and women in attendance at this series of meetings was fifteen hundred, of whom about one thousand registered for the American Association. The week was thus a very crowded one, the days being occupied with the meetings of the sections and the affiliated societies, and the general functions being as follows :-

On Monday evening, the annual address of the retiring president, Prof. Hall. Monday afternoon, the addresses of the retiring vice-presidents. On Tuesday evening, the address of the retiring president of the American Chemical Society, Dr. Remsen, and the public lecture of the American Society of Naturalists, delivered by Dr. C. Hart Merriam, on the subject "Protective and Directive Coloration of Animals, with especial Reference.to Birds and Mammals." On the same evening, the Botanical Society of Washington gave a reception to visiting botanists. On Wednesday afternoon, the annual discussion of the American Society of Naturalists was held; the subject was "How can Endowments be Used most Effectively for Scientific Research?" On the same afternoon, a public lecture, complimentary to the citizens of Washington, was given by Prof. I. C. Russell, of the University of Michigan, on "The Volcanoes of the West Indies." On Wednesday evening, the annual dinners of the American Society of Naturalists and the Geological Society of America, and the annual smoker of the American Chemical Society, were held.

On Thursday evening, the secretary of the Smithsonian Institution, Prof. Langley, held a reception in the National Museum.

On Friday afternoon, a lecture, complimentary to the citizens of Washington, was given by John Hays Hammond, on "Rhodesia, the Site of the Mines of King Solomon." Friday evening, the local committee, with the trustees of the Corcoran Art Gallery, gave a reception to the visiting members of the Association and the affiliated societies at the Art Gallery.

On Saturday morning, President Roosevelt received all visiting members at the White House.

Several important changes in the constitution of the Association went into effect at this meeting, all tending toward the improvement of the stability of the council and the sectional committees. Hereafter, the sectional committees will hold office for five years ; the secretaries of sections will also hold office for five years, and the council will elect annually three members at large to serve for three years. National scientific societies adopting permanent affiliation with the Association are now represented upon the council of the Association, and this body probably at' the present time includes a larger number of the active leading scientific men of America than any other organisation, not excepting the National Academy of Sciences.

Many notable papers were presented during the session, and the character of the proceedings, as will appear from the published reports in the journal Science, the organ of the Association, will undoubtedly show a very general improvement over the papers of previous meetings.

The general committee decided upon St. Louis as the next place of meeting, the time to be during Convocation Week of 1903-4, and recommended to the next general committee that Philadelphia be the following place of meeting during the Convocation Week of $1904-5$.

The officers elected for the St. Louis meeting are as follows :-

President, Carroll ID. Wright, Washington.

Vice-presidents :-Section A, Mathematics and Astronomy, O. H. Tittmann, Washington; B, Physics, E. H. Hall, Harvard University ; C, Chemistry, W. D. Bancroft, Cornell University; D, Mechanical Science and Engineering, C. M. Woodward, Washington University; E, Geology and Geography, I. C. Russell, University of Michigan ; F, Zoology, E. L. Mark, Harvard University; $G$, Botany, T. H. Macbride, University of Iowa; H, Anthropology, M. H. Saville, American Museum of Natural History; I, Social and Economic Science, S. E. Baldwin, New Haven; K, Physiology and Experimental Medicine, H. P. Bowditch, Harvard University.

General Secretary, C. H. Wardell Stiles, U.S. Revenue Marine Hospital and Public Health Service.

Secretary of the Council, Charles S. Howe, Case School.

Secretaries of the Sections :-Section A, Mathematics and Astronomy, L. G. Weld, University of Iowa; B, Physics, D. C. Miller, Case School ; C, Chemistry, A. H. Gill, Massachusetts Institute of Technology ; D, Mechanical Science and Engineering (no election); E, Geology, G. B. Shattuck, Baltimore ; F, Zoology, C. Judson Herrick, Denison University; G, Botany, F. E. Lloyd, 'Teachers' College, Columbia University; H, Anthropology, R. B. Dixon, Harvard University ; I, Social and Economic Science, J. F. Crowell, Washington; K, Physiology and Experimental Medicine, F. S. Lee, Columbia University.

The treasurer, Prof. R. S. Woodward, of Columbia University, and the permanent secretary, Dr. L. O. Howard, of the U.S. Department of Agriculture, remain unchanged.

\section{BUBONIC PLAGUE AT HOME AND ABROAD.}

$A$ VOLUME of reports and papers on bubonic plague $A$ has recently been issued by the Local Government Board, ${ }^{1}$ in continuation of the series originally commenced by the late Mr. Netten Radcliffe and since carried on by Dr. Bruce Low. In the preceding volume, Dr. Bruce Low carried the history of the distribution of plague throughout the world to the middle of 1898 , while the present report comprises the period from the middle of 1898 to the middle of 190 .

Dr. Low follows the occurrence and progress of bubonic plague chronologically and topographically by

1 "Reports and Papers on Bubonic Plague." By Dr. R. Bruce Low. With an Introduction by the Medical Officer of the Local Government Board. Pp. $x i+446$. (London: Eyre and Spottiswoode, 1902.) Price $4 s . x d$. 
the aid of a host of official documents, and partly from numerous other publications. To procure, sift, digest and arrange this enormous mass of polyglot literature is a task as complex as it is difficult, and, looking through the present volume, the reader will agree that Dr. Low has done a difficult piece of work in an exhaustive manner. The usefulness of such a work to the sanitarians of the world must be obvious. Dr. Low, in a clear and systematic and at the same time objective manner, describes the progress and general character of plague as it appeared in and as it affected the various countries during the period stated (middle of 1898middle of $\mathrm{I} 90 \mathrm{I}$ ); to this are added the official regulations and procedures in use in the different countries in dealing with plague.

As might be expected, the first place is given to England, Wales and Scotland; there being no case of plague recorded in Ireland, Dr. Low passes on to other European countries in which cases of plague have occurred, and then takes his readers into Turkey, the Levant, Arabia, South and Central Africa, India, the Far East, Australia and New Zealand, and finally America. As to the cases of plague that had been imported into England and Wales, it is satisfactory to learn from Dr. Low's account that the vigilance of, and procedures adopted by, our port sanitary officers were on the whole unremitting and thoroughly efficient; that whenever the case required it, the Local Government Board by its medical inspectors promptly and energetically assisted the port sanitary and local authorities in devising and carrying out the necessary protective and prophylactic measures. As a matter of fact, practically all the cases of plague that reached our shores were promptly intercepted and dealt with, and no further spread of the disease occurred.

Of no mean interest and importance are the facts collected by Dr. Low as to the relation of plague in the rat to plague in the human subject, and we cannot do better than quote here the concise summary on the subject by the Medical Officer of the Local Government Board (p. x).

"The records to which Dr. Low has had access, though they go to confirm belief that as regards plague man and the rat are reciprocally infective, fail completely in affording sufficient data for determining the degree to which man is in danger through the rat. So far as plague ashore is concerned, it would appear that in particular localities man and the rat suffered from plague coincidently; that in other localities man suffered before the rat; and that in others again the rat suffered antecedently to man. Further, it would appear that when in a particular district the one (man or the rat) has suffered plague antecedently to the other, the interval between invasion of the first and of the second species has been often a long one-extending sometimes over weeks and months. Finally, it would appear that plague may prevail largely among men without rats becoming conspicuously affected; and conversely that the disease may cause large mortality among rats of a locality while neglecting to attack its human inhabitants. As regards plague on shipboard, very similar facts were forthcoming. The disease does not, under conditions of sea transit, appear to be at all readily conveyed from the rat to man or from man to the rat. On the one hand, ships plagueinvaded for several weeks in the persons of crew or passengers have come into port with the rats on board them seemingly altogether exempt from disease ; and on the other hand, ships infected with plague-smitten rats have, after voyages of considerable duration, arrived at their destinations wholly free from plague as regards crew and passengers."

There is, then, no cause for the extreme views which some alarmists have put forward, i.e. those who would wish us to prevent any ship coming from an infected country from landing or discharging cargo unless previously all rats on board were destroyed, even in cases where no disease occurred amongst the crew or passengers. Such a procedure would, in the face of Dr. Low's array of facts, be quite unnecessary, and would inflict on shipping in general hardships which experience has shown would be scarcely justified even in the case of ships which on their voyage had actually been infected with plague.

(From the detailed account by Dr. Tidswell of the characters, origin and progress of the plague in Sydney, ${ }^{\mathbf{I}}$ it appears that the outbreak in man was preceded by great mortality amongst rats from plague, and, further, that the progress of the epidemic anongst human beings in different parts of the town was consistent with the dissemination of the contagion by rats.)

There is one further important point to be noted in the account by Dr. Low, and that is the comparatively simple and comprehensive manner in which plague-stricken or plague-suspected vessels arriving on our shores are dealt with, and the complete success which so far has attended the procedures both as to passengers and crew and cargo. These procedures contrast in a most favourable way with some of the doings in similar circumstances of the authorities in some other countries, in which countries machinery is put in action the chief object of which appears to be the most vexatious treatment of harmless passengers (vide s.s. Niger, Marseilles, p. I I 7).

The description of the epidemic of plague in Oporto in 1899 is very instructive reading, and throws into strong relief the broad fact, observed also in Glasgow (1900), in Alexandria, Bombay, the Cape and other places, how difficult, nay, impossible, it is to trace in these epidemics the origin of the outbreaks, the manner and channels in which the contagium had found entrance, and the lapse of considerable and most valuable periods before the disease as such is actually recognised. In these respects, England and Wales have so far been most fortunate in the Local Government Board having everywhere, in our seaports as well as inland, the attention of Medical Officers of Health early, and especially, directed to the danger of importation and to the best means to lessen it and to deal with any case should such occur. It is a fact that, in a good many instances, Medical Officers of Health have with laudable promptitude carefully taken account even of cases which from their clinical and epidemiological characters were not considered as cases of plague, but because they bore in one respect or another a resemblance to plague were notified and subjected to further examination. As was to be expected, these cases were proved not to have been cases of bubonic plague. On the other hand, the necessity for noting all such cases lies in this, that there are atypical cases of real plague which in clinical respects have only a distant resemblance to that disease such atypical cases of plague could, under less strict supervision, easily escape detection and be the starting point for dissemination of the disease.

A point of extreme interest to western countries is the comparison between the epidemics in the oriental, from which the present pandemic of plague started (I894), and the occidental countries into which it was imported and disseminated. The result of this comparison is highly gratifying, since it shows the very much lesser virulence of the disease in the occidental than in the oriental countries. The Medical Officer thus summarises these important facts (p. viii) :-

"There can be no question at all as to plague having very especially affected certain Oriental populations; outside the Asiatic continent, the disease has manifested small ability to become seriously epidemic. For instance, in India, plague, while year after year producing a heavy

I "Some Practical Aspects of the Plague at Sylney," by Dr. Frank Tidnwell (Journal of the Sanitary Institute, vol. xxi. patt iv.

No. 1735 , VOL. 67] 
rate of mortality, has at the same time proved exceptionally virulent, as shown by a high ratio of deaths to attacks; and this notwithstanding strenuous efforts on the part of well equipped sanitary bodies to obtain and to maintain control of the disease ; whereas in many other countries in various quarters of the world, not a few of them greatly inferior to India as regards administrative preparedness to resist imported disease, plague has failed, when introduced, to cause any but insignificant mortality, has not tended to recur from year to year, and has proved infinitely less virulent case for case than in better ordered India."

A detailed account of the regulations, orders, \&c., employed in all the affected countries, with ten carefully arranged coloured maps, form a valuable addition.

E: KLEIN.

\section{THE ARCHIVES OF PHONOGRAPHIC RECORDS.}

- HE Imperial Academy of Sciences of Vienna has recently appointed a commission to inquire into the possibilities of the application of the phonograph to scientific purposes. It would appear that this instrument has as yet been used mainly as a means of domestic recreation or as an adjunct to the penny showman, but it is quite clear that the instrument provides a means of preserving actual spoken specimens of languages, especially of those which are in a state of gradual development and growth or in a condition of decay. Moreover, by bringing the spoken speech or dialect of distant lands and out-ofthe-way districts to those to whom they would be otherwise inaccessible, a most valuable means of scientific research is made available. Recognising the latent possibilities of the phonograph in this direction, the Vienna Academy appointed the above-mentioned commission, the special task of which was the establishment, if possible, of central archives where phonographic records could be kept, duplicated and made accessible to the general scientific world.

The commission has recently issued its second report, dated July II, 1902, in which the position of affairs at that date is recorded.

The preliminary work undertaken was chiefly mechanical in nature and was concerned in the production of a standard instrument (Archiv-phonograph), and in working out the method of preservation and duplication of the records. It is, of course, self-evident that the wax record is unsuitable for preservation, and in order that this may be most conveniently copied in metal, the Archivphonograph has a flat wax plate instead of a cylindrical one. The instrument is shown in Fig. I. The "cast" wax plate is fixed on the round metal plate (24), which is caused to revolve round its centre by means of the gear shown, the driving force being a wound-up spring contained in the bottom case. The speed of rotation can be adjusted by means of the screw (32) and is indicated by a pointer in (33). The Edison recorder is contained in (7) and is caused to travel radially over the plate (24) so that the record is in the form of a spiral on the same; the distance between each line is $\frac{1}{4} \mathrm{~mm}$. It can be seen that the instrument is of very solid construction, and as such would be of more likely use for the laboratory than for purposes requiring its transport from place to place. The wax recommended is that used by Edison, and a plate is capable of taking a speech of two minutes' duration. The metallic negative is prepared as follows. The wax is removed from the instrument and peppered and brushed all over with very fine graphite, the current connection being made by a ring of copper wire stuck into the middle of the plate. Alcohol is then poured over the graphited plate, and it is at once placed in the electrolytic bath and copper deposited thereon. The so- formed negative is sprung from the wax, cleaned and polished, and flashed over with a very thin layer of nickel in a nickel bath. These metal "phonotypes" are used as patterns for casting the "Archiv" plates in wax which are used in the phonograph for the reproduction of the acoustic record. The metal negatives are, of course, durable and are kept, and as many "Archiv" plates can be cast off them from time to time as may be desired.

In order to put the ideas underlying the appointment of the commission to practical test, three scientific expeditions recently sent out by the Vienna Academy were each provided with an Archiv-phonograph, and the reports furnished by the leaders of these expeditions are given. The expeditions were two philological ones to Kroatia and Slavonia and Lesbos respectively, and a geological one to Brazil. It is evident from the reports that the, it is true, interesting and valuable records obtained were only got by dint of much trouble and perseverance, as the apparatus for such purposes is most unsuitable, the whole outfit weighing, as it does, I2O kilogrammes. Such an apparatus may be compared to a photographic artist's studio camera, while what is required is something more of the nature of a hand camera. It was found impossible to remove the phonograph any distance from the railway, so that very

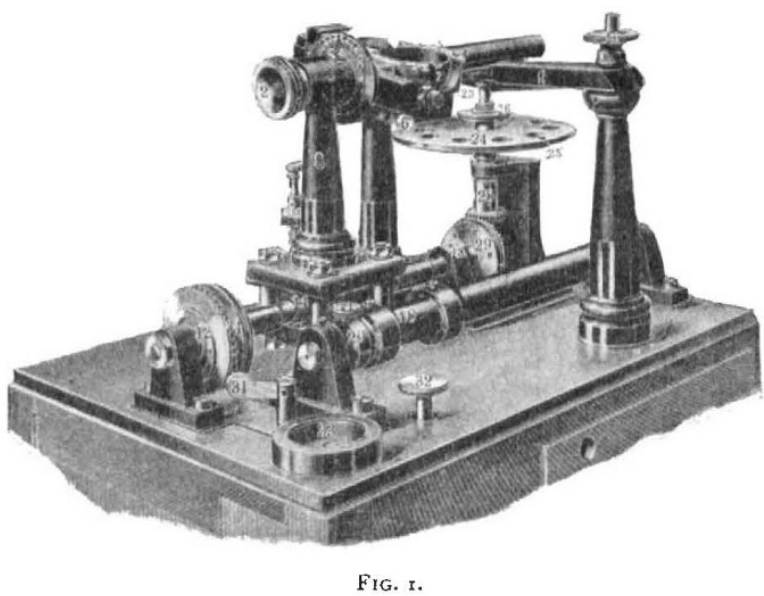

interesting records of dialects, \&c., which could otherwise have been obtained were not possible to be got. However, there is no reason why, with proper design, an instrument may not be worked out which will fulfil the practical and mechanical conditions required; the main thing to be settled by the present experiments was if the records obtained and preserved are of real scientific value. The records brought back were, therefore, treated in the above-delineated manner, and the "Archiv" plates obtained submitted to the leaders of the expeditions and to other authorities, who reported that they gave, as a rule, a good reproduction of the original speech and words, from which it may be concluded that the method adopted is a success and capable of much use in the future. Of course, certain limitations, such as the differentiation of similar consonants, \&c., have to be recognised, and whether the phonograph is capable of such improvement that it will get over these remains to be seen; at any rate, if the establishment of the phonographic archives is a success, it is likely that our descendants one or two thousand years hence will not find themselves in the same predicament as to our present pronunciation as we are as to that of our Latin and Greek, not to mention other dead languages, and that besides this advantage to our posterity, valuable service to science of the present day will result. C. C. G. 